Indonesian Journal of EFL and Linguistics

Vol. 2 No. 2, 2017

eISSN: 2503-4197, pISSN: 2527-5070

www. indonesian-efl-journal.org

\title{
The Impact of Language Policy in the Basic Education Core Curriculum in Thailand
}

\author{
Khattiyanant Nonthaisong \\ Princess Chulabhorn's College Buriram, Thailand \\ Miguel Mantero \\ The University of Alabama, United States \\ e-mail:mmantero@ua.edu
}

\begin{abstract}
:
Over the last 10 years, much research has been completed in the area of English language policy in Thailand. The majority of studies have focused on the pedagogy and methods involved in the teaching practices of Thai EFL educators at primary school level (Prapaisit de Segovia \& Hardison, 2009; Tongpoon-Patanasorn, 2011;:Li, 2017) and secondary school level (Darasawang \& Watson Todd, 2012; Nonkukhetkhong, Baldauf, \& Moni, 2006). The present study delves deeper into teaching practices and addresses how English language policy is perceived and interpreted at the classroom level through the practices of Thai English teachers in a rural government secondary school in the northeast part of the country. To date, there is only one study which examines the impact of English language policy in the core curriculum on the teaching practices of EFL teachers at both primary and secondary school level has been completed (Fitzpatrick, 2011). In an effort to frame the present study, we apply Hornberger's (2006) integrative framework as an attempt to support case study methodology. This approach provided us the opportunity to research "one or more instances of a phenomenon in its real-life context that reflect the perspective of the participants involved in the phenomenon" (Gall, Gall, \& Borg, 2007, p. 447). And, it offered a grounded view of how this English language policy is being enacted in Thailand.
\end{abstract}

Keywords: Language Policy, Basic Education, Core Curriculum

Indonesian Journal of EFL and Linguistics, 2(2), 2017 


\section{ENGLISH IN THAILAND}

Generally, English has been used in Thai society to aid social mobility, allowing those that learn and use it to have more access to political and economic power (Baker, 2008). English has been linked to middle and upper middle classes; it has been used as a form of gate keeping with respect for the university entry for their children, meaning that other students who perform poorly in English may not be able to get into the institution of their choice. However, English still has little relevance for the majority of Thai lives in general. In Bangkok and other major tourist cities like Chiang Mai or Phuket, foreigners can communicate even though they do not know Thai language since most people can communicate with basic English. On the other hand, if they go to the small cities or rural areas in Thailand, the chance to communicate in English is almost nonexistent.

Thailand is the only country in Southeast Asia which has never been colonized and is described by Kachru as a nation in the "expanding circle" of English users in Asia (1998, p. 93) where English is primarily used as a foreign language for education and business purposes. English was first introduced in Thailand in the 17th century for the purpose of modernizing the country in response to the threat of Western colonization and the pressure of internal politics (Darasawang, 2007). It was first taught to a group of elites in the royal schools, and in later years opportunities were open to common people when more schools for commoners were established. English language in Thailand has gone through a considerable evolution ever since and has always maintained its status as a foreign language.

In 2010, there was an attempt by the Minister of Education to promote improved learning of English, suggesting that English should be made the official second language of the country (Darasawang \& Watson Todd, 2012). He further proposed that he would import thousands of native-speaker teachers and upper secondary school math and science instruction would be taught in English. Nevertheless, because of the strong criticism that it could lead to the misunderstandings that Thailand had been colonized in the past, he immediately withdrew this proposal.

Internationally, the role of English has become more crucial for Thailand and the other nine neighboring countries in the region as a lingua franca since 2009 when it was adopted as the official working language of the ASEAN (Association of Southeast Asian Nations) (Kirkpatrick, 2012). In 2015, the ASEAN Economic Community (AEC) will bring together the 10 ASEAN members, including Brunei, Myanmar, Cambodia, Indonesia, Laos, Malaysia, the Philippines, Singapore, Thailand, and Vietnam, into a single market to compete in the global economy. This economic integration will provide for the free movement of trade, labor, and capital within the region. Therefore, in order to work effectively and compete with other countries in the region, Thailand does need to develop English communicative skills for its people who are now considered at low level of English proficiency, compared to the neighboring countries in the region (Assavanonda, 2013).

In response to the crucial role of English in the globalization era, Thailand reformed its language policy with the goal of improving communicative abilities in English 
for Thai citizens as well as providing a more supportive, clearer framework for English instruction throughout the educational system (Ushioda, 2017; Nunan, 2003; Wongsothorn, 2000).

Currently, the English language policy has been mainly implemented at a national level by the Office of Basic Education Commission (OBEC) in the Ministry of Education. The present curriculum was revised from the Basic Education Curriculum B.E. 2544 (A.D. 2001) in order to provide clearer guidelines on how the major learning areas should be taught and assessed (Ministry of Education, 2008). These eight learning areas include: Thai language; mathematics; science; social studies, religion, and culture; health and physical education; arts; occupations and technology; and foreign languages.

Within these guidelines, English is made compulsory from Prathom 1 (Equivalent to Grade 1) in primary school to Mattayom 6 (Equivalent to Grade 12) in secondary school. While students take a minimum of 1 hour of English a week in primary school, secondary school students take at least 3 hours of English a week. Moreover, English is one of the compulsory subjects for the Ordinary National Educational Test (O-NET) which students are required to pass in order to graduate at the primary (Prathom 6), lower secondary (Mattayom 3), and upper-secondary (Mattayom 6) school levels. Mattayom 6 students also need these O-NET scores for university admission. Other foreign languages can be offered as elective courses for students in upper- secondary school level.

The main function of this curriculum is to develop communicative language skills with an emphasis on a student-centered and communicative approach to teaching. The curriculum's goal, especially related to English language education, is to decentralize educational authority and to enable local communities and schools to participate and prepare curricula which reflect their needs. Teachers are also encouraged to create or adopt materials that reflect the policy aims and the needs of their schools and communities. Thus, in the classroom level, EFL teachers are considered to have main roles in putting the policy into practice. Additionally, they are likely to be a main indicator of success and failure of the policy implementation. Given this, the following question guides and frames the present study: How do Thai EFL teachers understand the goals of the English language policy in the Basic Education Core Curriculum B.E. 2551 (A.D. 2008) and how is this understanding enacted in their pedagogy?

\section{APPROACHING THE STUDY}

Language policy is purposeful effort to influence the function, structure, or acquisition of languages within a community. And, beyond the official guidelines included in language policy statements and language laws, Shohamy (2006) argued that language policy occurs through a variety of additional devices, some overt, other covert and hidden, including rules and regulations, language education policies, language tests, and language in the public space. Ricento (2006) also noted that language policy and its implementation is a rather complex process and very difficult to evaluate. However, Hornberger (2006) offered a framework, containing 
three types of planning - status, acquisition and corpus - to aid in the comprehension of the intricacies involved in language policy. We apply Hornberger's framework with the hope that it will help us disentangle the complex processes and influence of language policy in educational settings.

Table 1

Language Policy and Planning Goals: An Integrative Framework

\begin{tabular}{|c|c|c|}
\hline $\begin{array}{l}\text { Approaches } \\
\text { Types }\end{array}$ & $\begin{array}{l}\text { Policy planning } \\
\text { (on form) } \\
\text { Goals }\end{array}$ & $\begin{array}{l}\text { Cultivation planning } \\
\text { (on function) } \\
\text { Goals }\end{array}$ \\
\hline $\begin{array}{l}\text { Status planning } \\
\text { (about uses of } \\
\text { language) }\end{array}$ & $\begin{array}{l}\text { Officialization } \\
\text { Nationalization } \\
\text { Standardization of status } \\
\text { Proscription }\end{array}$ & $\begin{array}{l}\text { Revival } \\
\text { Maintenance } \\
\text { Spread } \\
\text { Interlingual communication- } \\
\text { International, intranational }\end{array}$ \\
\hline $\begin{array}{l}\text { Acquisition } \\
\text { planning (about } \\
\text { users } \\
\text { language) }\end{array}$ & $\begin{array}{l}\text { Group } \\
\text { Education/School } \\
\text { Literacy } \\
\text { Religious } \\
\text { Mass media } \\
\text { Work }\end{array}$ & $\begin{array}{l}\text { Reacquisition } \\
\text { Maintenance } \\
\text { Shift } \\
\text { Foreign language/ second } \\
\text { language/ } \\
\text { Literacy }\end{array}$ \\
\hline $\begin{array}{l}\text { Corpus planning } \\
\text { (about } \\
\text { language) }\end{array}$ & $\begin{array}{l}\text { Standardization of corpus } \\
\text { Standardization of auxiliary code } \\
\text { Graphization }\end{array}$ & $\begin{array}{l}\text { Modernization (new functions) } \\
\text { Lexical } \\
\text { Stylistic } \\
\text { Renovation (new forms, old } \\
\text { functions) } \\
\text { Purification } \\
\text { Reform } \\
\text { Stylistic simplification } \\
\text { Terminology unification }\end{array}$ \\
\hline
\end{tabular}

In Table 1, above, status is concerned with the way languages are used; corpus deals with how a language is constituted; while acquisition planning generally refers to how a national government system aims to influence aspects of language, such as what languages should be taught in the curriculum, or what materials will be used and how they will be incorporated into syllabi. In addition, she included two main approaches that deal with form (policy planning) and function (cultivation planning). The policy planning refers to macro-issues such as standardizing forms of a language, while cultivation planning is connected to smaller, micro-issues that include the maintenance of a language.

\subsection{Research Design}

Since this study explores the understandings and experiences of Thai EFL teachers within natural settings, it lent itself to qualitative inquiry, and more importantly, a multiple case study design. Case study methodology helps to guide an "the in-depth study of one or more instances of a phenomenon in its real-life context that reflect the perspective of the participants involved in the phenomenon" (Gall et al., 2007, p. 447) and it offers us ways to understand the world as seen by participants in the 
phenomenon (Yin, 2003). Additionally, Gall et al. (2007) explained case studies are pursued for one of these three general purposes: to produce detailed description of a phenomenon, to develop possible explanation of it, or to evaluate the phenomenon. Data for case studies can be collected using many sources of information in the natural setting of the phenomenon, including interviewing, document collection and analysis, behavioral observation, as well as visual images, such as photographs, drawings, and film (Swanborn, 2010) since a variety of data sources allows us to better understand the phenomenon from multiple lenses.

\subsection{Setting and Participants}

The study took place in Buriram, 1 of 19 provinces in the northeastern part of the Thailand, known as Isan, which is regarded as the poorest part of the country (Fry \& $\mathrm{Bi}, 2013)$. Buriram is situated in the lower part of Isan region, about 410 kilometers from Bangkok. It has a population of $1,573,438$ people. The province is well-known for its ancient ruins, extinct volcanoes, and agricultural products. The setting of the study is a government secondary school located in the northeastern part of the province, about 60 kilometers from the provincial capital and 10 kilometers from its district. This school is considered as a sub-district secondary school situated in a village with approximately 400 students who come from 14 villages surrounding the school. Thai is the language of the classroom, but many of the students speak Isan (Lao), Khmer, or Suay as their first language. School facilities were generally very good. In addition to having access to a library, a science laboratory, computer rooms as well as a Wi-Fi, there is a projector with a screen and an audio system with two speakers available in almost every classroom. This school currently has two EFL teachers: Nattaporn and Kwan (pseudonyms)

Nattaporn is 46 years old. She has a Bachelor's Degree in English (B.Ed.) and a Master's Degree in Administration (MA.). She speaks Thai, Isan, and English. She has been teaching English for 23 years and has been at the current school for 20 years. She has taught English for all class levels: from Mattayom 1 to 6. During the semester the study took place, she was teaching Fundamental English for Mattayom 3 and Mattayom 5. She taught 16 fifty-minute classes per week. Apart from teaching, she is a department head and also works as a school accountant.

Kwan is 51 years old. She has a Bachelor's Degree in English (B.Ed.) and a Master's Degree in Administration (M.A.). She speaks Thai, Isan, Khmer, Suay, and English. She has been teaching English for 12 years and has been at the current school for 3 years. Like Nattaporn, she has taught English for all class levels: from Mattayom 1 to 6 . In the semester the study took place, she taught Fundamental English for Mattayom 6 and Elective English for Mattayom 4 and 6. She teaches 16 fifty-minute classes per week. For her school duties, she is responsible for the school bank project and the school infirmary.

\section{DATA AND ANALYSES}

The three sources of data-interviews, classroom observations, and document analysis-give the researcher different perspectives on how the secondary school English teachers interpret and put the current English language policy into practice 
in their local environment. In addition, we engaged in member checking with the participants. Member checking, which involves having research participants review statements in the transcriptions and the report for accuracy and completeness, can be done to increase the trustworthiness of the study (Gall et al., 2007). The first member checking took place after the interview transcriptions were completed; the participants were asked to confirm the transcriptions of the interviews. The second member checking took place when the analysis was finished and was done via email; the participants were encouraged to review the analysis and interpretations. Finally, peer debriefing, which involves having colleagues provide "an external check on the inquiry process" (Lincoln \& Guba, 1985, p.301), was utilized. We asked the instructors to engage in peer debriefing in order to provide comments on findings as they emerged as well as to review a draft of the current findings.

\subsection{Document Analysis}

The purpose of document analysis is to gain insight into the activities the teachers use in the classroom. Information was gathered from official documents related to this theme: Ministry of Education documents, curriculum documents, and teaching materials. These included the Basic Education Core Curriculum B.E. 2551 (A.D. 2008) as well as the English curriculum which the school developed from this national core curriculum and used in the school. These documents, along with other written records such as textbooks, lesson plans, teaching materials, and tests were mainly used to supplement the researcher's understanding of how the English language policy was being conceptualized by this group of local teachers.

\subsection{Classroom Observations}

In order to gain better understanding on how the EFL teachers at the secondary school level interpreted the English language policy in the Basic Education Core Curriculum B.E. 2551 (A.D. 2008) and put it into their teaching practice in the classroom context, a total of 12 classroom observations were conducted in 3 weeks; 6 classroom observations for each of the participants. It is important to note that each of the participants taught at least two of these grade levels (Mattayom 1-6) and the classroom observations were conducted with all grade levels that each participant taught. In the preliminary meeting with the teachers, we offered them a selection of dates and times for the observations so that they could choose the most suitable for them in each week. We started our classroom observations in the middle of June after the new term had run for a month. We did not make any suggestions on what kind of lesson would be taught. Our roles in this study were as observers and sat at the back of the classroom. During each observation, which lasted about 50 minutes, field notes all the teaching activities were taken. These included such activities as how many times the teacher used the board, the organization of the students into pairs or groups, how student feedback was delivered, the use of materials, as well as L1 and L2 usage. 


\subsubsection{Kwan's class}

The majority of the data from her classroom observations $(83 \%)$ can be categorized as 'foreign language/second language/literacy'. Kwan's teaching style can be summarized as presentation, practice, and production.

Some samples of what she did in her class while she was teaching a conversation about the situation in the restaurant:

After greeting students and reviewing the words they learned in the previous class, she presented the new lesson by having students watch three model conversations from YouTube. She played each model conversation three times; for the second and third time, each model conversation was shown with English subtitle, together with a Thai pronunciation and meaning of each model conversation. During the presentation, she discussed what happened in the video with students mostly in Thai, as well as discussed the meaning of some words from the video. During the second time, she asked students to take note from the video while they were watching it. And during the third time, she asked them to repeat after the video and then after her. Then she discussed with her students briefly about the culture of giving tips in Western countries and Thailand. After that, as for summarizing the lesson, she played the cartoon version of the conversation (it included most of what they had learned in model conversations 1-3). The first time, students watched the video with the English subtitle. The second time, they watched the Thai dubbed version of the conversation. The teacher had them watch both versions twice. Finally, as homework, she asked them to write their own conversation for a restaurant situation; one conversation for each student.

Fifteen percent of data from Kwan's classroom observations can be viewed as both 'foreign language/second language/literacy' and 'interlingual communication'. According to Hornberger's (2006) integrative framework, Kwan understood the goals of the English language policy in the Basic Education Core Curriculum B.E. 2552 (A.D. 2008) not only as the process of teaching and learning foreign language/second language/literacy in school but also as the facilitation of linguistic communication between members of distinct speech communities. This means that Kwan helped students to use English to communicate with her and other students in the classroom. For instance, she asked students what a preposition was, and no one answered. She started giving them examples of sentences using prepositions: "The book is on the table" and "Mayuree is sitting on the chair". There was one student shouting out the answer, "Poophabot" (Thai word for 'preposition'). In another example, when some students asked for her permission to come into the classroom in Thai, she asked them to say it in English, "Say it in English, please." Finally, she let them in the classroom when they asked her one by one, "May I come in, please?".

Two percent of data from Kwan's classroom observations can be viewed as both 'foreign language/second language/literacy' and 'spread.' Kwan also understood the goals of the English language policy in the Basic Education Core Curriculum B.E. 2551 (A.D. 2008) as both the process of teaching and learning foreign 
language/second language/literacy in school and the attempt to increase the number of speakers of one language at the expense of another language. However, 'spread' here is not inferred directly to increase the number of speakers of English but instead to make students aware of the importance of learning English rather than other foreign languages since it is one of the subjects they have to take in the national test. For example, as a warm-up activity in one of her classes, Kwan had students practice doing three questions of the past Ordinary National Educational Test (ONET), a national test. She asked students to read the test question from the handout they already had and they discussed the best answer for each question. She gave students tips on answering the question and asked them to take notes.

The field notes taken while observing Kwan in six classes indicated that she understood the goal of the English language policy in the Basic Education Core Curriculum B.E. 2551 (A.D. 2008) mainly as 'foreign language/second language/literacy' in acquisition planning. Also, she understood the goals of the English language policy as 'foreign language/second language/literacy' in acquisition planning and 'interlingual communication' in status planning. Finally, she understood the goals of the policy as 'foreign language/second language/literacy in acquisition planning' and 'spread' in status planning, according to the integrative framework by Hornberger (2006, p. 29).

\subsubsection{Nattaporn's Class}

The majority of data from Nattaporn's classroom observations can be viewed as 'foreign language/second language/literacy'. Like Kwan, Nattaporn's teaching style can be summarized as presentation, practice, and production.

Here are some samples of what she did in her class while she was teaching conversation:

After greeting the students, she made sure that students were ready to learn by asking them to take out their learning materials using simple expressions in English like, "Where is your notebook?" and "Where is your dictionary?". For the presentation of the new lesson, she started by asking students to look at the picture next to the conversation in their textbooks before she asked them, "Who are they?", but no one answered. Thus, she started reading the conversation from the textbook and at the same time trying to discuss the meaning of the unknown words with students. After she read the conversation, she asked students to look at the picture next to the conversation again and asked them, "What is he doing?" and "What is she doing?". She then translated the two questions right away in Thai, and ended up answering the questions by herself, "He is writing"; "She is talking with her friends". For students to practice the conversation, Nattaporn asked them to read after her as a whole class first before asking the boys to read as Kevin, the man in the conversation, and the girls as Julie, the woman in the conversation. After that, she had them practice in pairs and she walked around the classroom to check how they worked. Before the class ended, she assigned students to read in pairs as a test in the next class; they had to read and translate the conversation in Thai. 
Similar to Kwan, $15 \%$ of data from Nattaporn's classroom observations can be viewed as both 'foreign language/second language/literacy' and 'interlingual communication'. Apart from viewing what Nattaporn did in the classrooms as the process of teaching and learning foreign language/second language/literacy in school, it can be also considered as a way to facilitate her students to use English to communicate with her and other students in class. For instance, at the beginning of all the six classes we observed, students had to ask for permission to come in the classroom in English when they came late to the class. If they did not ask for permission in English, they were not allowed to come inside the classroom. In another example, when she wanted to elicit the meaning of the word 'close' she assumed that every student knew the meaning of the word 'open' which is an antonym of the word 'close.' Therefore, she asked the students the meaning of the word 'open' in order to elicit the meaning of the word "close' from the students and she got the answer from them.

All the field notes taken while observing Nattaporn in six classes indicated that she understood the goal of the English language policy in the Basic Education Core Curriculum B.E. 2551 (A.D. 2008) mainly as 'foreign language/second language/literacy' in acquisition planning. She also understood the goals of the policy as 'foreign language/second language/literacy in acquisition planning and 'interlingual communication' in status planning.

\subsection{Interviews with the teachers}

The purpose of the interviews was to gain information on how the EFL teachers at the secondary school level perceived and interpreted the English language policy in the Basic Education Core Curriculum B.E. 2551 (A.D. 2008) as well as how they put it into practice in their classrooms. Two semi-structured interviews were conducted with the two participants: the first interview took place 1 day after the second classroom observation finished and the second interview were conducted 2 weeks after the sixth classroom observation finished. The interview protocol included questions about the new English curriculum, approaches to teaching, teaching materials, tests and evaluations, and the roles of English. Moreover, the additional questions built on themes emerging from classroom observations and document analyses were also included in the interviews to clarify and confirm the understandings of how and why the teachers did things in the classrooms. The semistructured interview, which lasted from 40 to 60 minutes, was conducted in Thai language which the two participants were comfortable with. Without a language barrier, they could share their deeper level of experience which provided richer and more accurate information for the study (Koulouriotis, 2011; Li, 2011). These interviews were audio-recorded, transcribed, and translated into English by the researcher. The English translations of the interview salient for data analysis were rechecked by the translation rater.

\subsection{Kwan's interview}

Data from both interviews indicated Kwan understood the goal of the English language policy in the Basic Education Core Curriculum B.E. 2551 (A.D. 2008) 
mainly as 'foreign language/second language/literacy' in acquisition planning. Second, she understood the goals of the English language policy as 'foreign language/second language/literacy' in an acquisition planning and 'spread' in status planning. Third, she understood the goals of the English policy as 'foreign language/second language/literacy' in acquisition planning and 'interlingual communication' in status planning. Finally, she also understood it as 'foreign language/second language/literacy' in acquisition planning, 'spread' and 'interlingual communication' in status planning.

Eighty-four percent of the interview data can be categorized as 'foreign language/ second language/ literacy' data can be categorized as 'foreign language/second language/literacy'. For example, when asked what she thinks what the characteristics of English teaching and learning in Thai schools are, Kwan answered that the teachers used grammar translation method in their classes, and students were asked to learn each tense by heart. She also mentioned that it was rare to see students use English to communicate. In another example, when asking her to explain briefly how she planned her lessons, Kwan mentioned that she would check how many chapters she could use to suit the course syllabus developed from the school curriculum. Then, she would prepare a weekly lesson plan: what to teach, how many hours, how to evaluate students, and what criteria to use. After that she would continue writing a detailed lesson plan, including classroom activities that went with indicators or objectives of each lesson. During the interview, she showed me her course syllabus and weekly lesson plan.

A much smaller portion of the interview data $(9 \%)$ can be categorized as both 'foreign language/second language/literacy' and 'spread'. Kwan also understood the goals of the English language policy in the Basic Education Core Curriculum B.E. 2551 (A.D. 2008) both as the process of teaching and learning foreign language/second language/literacy at school and the attempt to increase the number of speakers of one language at the expense of another language. However, as mentioned earlier in the classroom observation finding section, 'spread' here seems to refer to as making students aware of the importance of learning English rather than other foreign languages instead of directly increasing the numbers of the speakers of English. For instance, in the interview, Kwan described how her lessons focus on making students to have good attitude toward English. She wanted to make English learning fun and not too serious so that students might enjoy learning it. She also emphasized the importance of learning English by mentioning what she did in her class to help students be familiar with the O-NET test. She stated the following:

When I taught Mattayom 3, I included 1-2 questions from the O-Net for students to practice in each class, generally at the beginning of the class. I focus[ed] on the first part of the test, a situational dialogue part. I presented the students at least one situation per class and asked them to practice doing the test, and then I explained and encouraged students to discuss the answers.

A minimal part of the interview responses (5\%) can be viewed as both 'foreign language/second language/literacy' and 'interlingual communication'. This indicated that Kwan understood the goals of the English language policy in the Basic 
Education Core Curriculum B.E. 2551 (A.D. 2008) both as the process of teaching and learning foreign language/second language/literacy in school, as well as the way to facilitate her students to use English to communicate. For instance, Kwan stated her main goals in teaching as follows:

My goal in teaching English is to help students to use English for communication; they can read and write, as well as use it in their daily life and use it to further their study.

Few responses from the interview (2\%) can be categorized as 'foreign language/second language/literacy', 'spread', and 'interlingual communication.' This indicated that Kwan understood the goals of the English language policy in the Basic Education Core Curriculum B. E. 2551 (A.D. 2008) as the process of teaching and learning foreign language/second language/literacy in school, the attempt to increase the number of speakers of English at the expense of another language, as well as the way to facilitate her students to use English to communicate. As Kwan stated in her interview, she stressed the importance of using English for communication for Thai people when Thailand join the AEC (Asean Economic Community) in 2015. Thus, she suggested that school should have activities that help their students to use English for communication. As one way to do this, she assigned students to practice a short English conversation and had them perform in the school morning assembly.

\subsection{Nattaporn's interview}

Like Kwan, data from both interviews indicated Nattaporn also understood the goal of the English language policy in the Basic Education Core Curriculum B.E. 2551 (A.D. 2008) mainly as 'foreign language/second language/literacy' in acquisition planning. Second, she understood the goals of the English language policy as 'foreign language/second language/

literacy' in acquisition planning and 'spread' in status planning. Third, she understood them as 'foreign language/second language/literacy' in acquisition planning and 'interlingual communication' in status planning. Finally, she also understood the goals of the English language policy as 'foreign language/second language/literacy' in acquisition planning, 'spread' and 'interlingual communication' in status planning.

The majority of Nattaporn's responses $(86 \%)$ can be categorized as 'foreign language/second language/s. For example, when asking her what she thought the characteristics of English teaching and learning in Thai schools were, Kwan described how the teachers in Thai schools taught according to the textbooks they used. She also thought that they had to teach all four skills together in each class. For example, when asking her to explain briefly how she planned her lessons, Nattaporn stated that she usually studied the curriculum first, looking at the themes and finding the content that matched each theme. She then made it into units and put the content in each unit: what activities she would use, as well as on what and how to assess the students. Nonetheless, as their school decided to use a textbook beginning this year, she stressed that she had to start with the textbook first. 
A smaller part of her responses $(8 \%)$ be categorized as both 'foreign language/second language/literacy' and 'spread'. Similar to Kwan, Nattaporn also understood the goals of the English language policy in the Basic Education Core Curriculum B.E. 2551 (A.D. 2008) both as the process of teaching and learning foreign language/second language/literacy at school and the attempt to increase the number of speakers of one language at the expense of another language. For example, as an attempt to make students aware of the importance of English and make them want to use the language, Nattaporn stated that their school provided an English camp for Mattayom 1 students. She said that they had student teachers from Mahasarakham University to help prepare and organize the camp. Unlike Kwan, in order to help students with the national test, she stated that she tutored her students on the extra class that their school prepared for students 1 week before students took the O-NET test; she prepared some past tests and had students practice doing them.

There were only a few instances (4\%) which could be seen as both 'foreign language/second language/literacy' and 'interlingual communication.' This indicated that Nattaporn understood the goals of the English language policy in the Basic Education Core Curriculum B.E. 2551 (A.D. 2008) both as the process of teaching and learning foreign language/second language/literacy in school, as well as the way to facilitate her students to use English to communicate. As stated in the interview, Nattaporn wanted to teach English based on the prescribed curriculum and she wanted her students at least to be able to communicate in basic English. For her students, she thought that they needed English for continuing their studies and some of them needed it for their future work.

Only a couple of times did Nattaporn mention items which were seen as 'foreign language/second language/ literacy', 'spread', and 'interlingual communication.' This indicated that Nattaporn understood the goals of the English language policy in the Basic Education Core Curriculum B.E. 2551 (A.D. 2008) as the process of teaching and learning foreign language/second language/literacy in school, the attempt to increase the number of speakers of English at the expense of another language, as well as the way to facilitate her students using English to communicate. Similar to Kwan, Nattaporn also mentioned that she had students present something about English that people can use in their daily lives at the school morning assembly; some students presented useful English words and some presented a short conversation. She also stated that she wanted them to have good attitude toward English.

Based on the data from classroom observations of both Kwan and Nattaporn, $84 \%$ can be viewed as 'foreign language/ second language/ literacy' in acquisition planning. In addition, 15\% can be viewed as both 'foreign language/ secondary language/ literacy' and 'interlingual communication' in status planning. And 1\% can be viewed as both 'foreign language/ secondary language/ literacy' and 'spread' in both acquisition planning and status planning. 


\title{
Kwan and Nattaporn's Interview Data
}

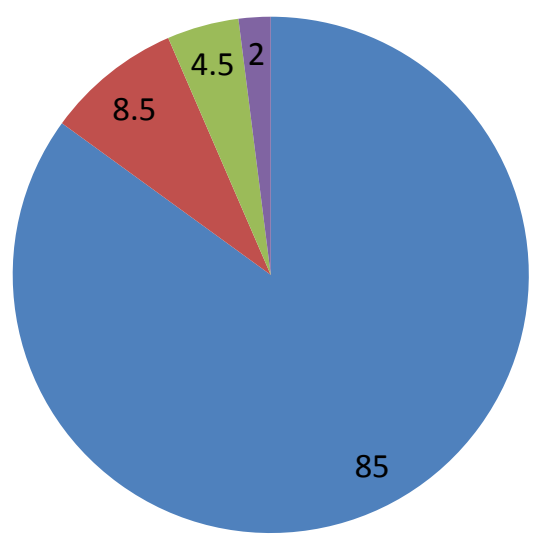

\author{
foreign language/ second \\ language/ literacy \\ foreign language/ second \\ language/ literacy and spread \\ foreign language/ second \\ language/ literacy and \\ interlingual communication
}

\section{DISCUSSION}

The EFL teachers who put the English language policy into practice seemed to understand the goals of the English language policy in the Basic Education Core Curriculum B.E. 2551 (A.D. 2008) mainly as 'foreign language/second language/literacy' in acquisition planning with some of their understandings fall on the concepts of 'spread' and 'interlingual communication' in status planning. This finding corresponds to the policy planning adopted by the English language policy in the Basic Education Core Curriculum B.E. 2551 (A.D. 2008), previously noted as acquisition planning and status planning.

\subsection{Acquisition planning.}

The major area in which the policy planning and cultivation planning approaches for the English language policy in the Basic Education Core Curriculum B.E. 2551 (A.D. 2008) have been carried out is acquisition planning. As previously discussed, Hornberger (2006) described acquisition planning as how a national government system aims to influence aspects of language.

According to Hornberger's (2006, p. 29) integrative framework, for a policy planning approach, the main goal that the English language policy in the Basic Education Core Curriculum B.E. 2551 (A.D. 2008) adopts is 'education/school' which is in acquisition planning. Similarly, using the same framework, Fitzpatrick (2011) noted that his study of English language policy in Thailand adopted acquisition planning because it deals with Thai speakers of English. Also noted by Darasawang and Watson Todd (2012) and Chan and Lo (2017), education is a major area through which the language policy is implemented in Thailand. At the national level, the Office of Basic Education Commission (OBEC), Ministry of Education has implemented the English language policy through the Basic Education Core Curriculum B.E. 2551 (A.D. 2008). This curriculum prescribed English as the main 
foreign language taught in schools from Prathom 1 (Grade 1) in primary school to Mattayom 6 (Grade 12) in secondary school. The aims of this learning area are for learners to be able to have a favorable attitude toward foreign languages, to be able to communicate in various situations, pursue knowledge, engage in a livelihood, and take advantage from further education at higher levels (Ministry of Education, 2008). In terms of teaching, the emphasis is on a more student-centered and communicative approach with some learning contents on their local context.

For a cultivation planning approach (Hornberger, 2006, p. 29), there are four goals: reacquisition, maintenance, shift, and foreign language/second language/literacy. To put this into the context of the current study, the EFL teachers who put the English language policy in the Basic Education Core Curriculum B.E. 2551 (A.D. 2008) into practice understood the goal of the English language policy as 'foreign language/second language/literacy,' which as previously defined is the process of teaching and learning foreign language/second language/literacy in school (Kaplan \& Baldauf Jr., 2005). In this case, this means that the EFL teachers understand the goal of the policy as teaching and learning English as a foreign language. Both EFL teachers were aware of the goals of the English language policy emphasized in the Basic Education Core Curriculum B.E. 2551 (A.D. 2008). During the interviews and classroom observations, they both made references to the concepts of a studentcentered and communicative approach to English teaching several times. In addition, for their students to use English to continue their studies, both teachers stated that they wanted their students to be able to use English to communicate in daily life as well. As for the goal of creating or adapting contents relating to their local community, they both reported that they did not have this portion in their lessons.

\subsection{Status planning.}

Status planning is another area in which the policy planning and cultivation planning approaches for the English language policy in the Basic Education Core Curriculum B.E. 2551 (A.D. 2008) has been carried out. Hornberger (2006) referred to status planning as the uses of languages.

According to Hornberger's (2006, p. 29) integrative framework, for a policy planning approach, the English language policy in the Basic Education Core Curriculum B.E. 2551 (A.D. 2008) also adopted the goal of 'officialization.' As Shohamy (2006) pointed out, language policy occurs through several additional devices; it is included in not only language policy statements and language laws but also language education policies and language tests. Despite the fact there was no official statement on the English language in the curriculum. English is positioned as a main foreign language taught in Thai schools because its learning content is prescribed for the entire curriculum for a learning area of foreign languages (Ministry of Education, 2008). In other words, English is made compulsory for students from Prathom 1 (Grade 1) in primary school to Mattayom 6 (Grade 12) in secondary school. In addition, English is one of the learning areas included in the Ordinary National Educational Test (O-NET) which students need to pass for completion in each school level: level 1 (Prathom 6-Equivalent to Grade 6), level 2 (Mattayom 3-Equivalent to Grade 9), and level 3 (Mattayom 6-Equivalent to Grade 
12). Importantly, in addition to their Grade Point Averages (GPA), the Ordinary National Educational Test (O-NET scores are also needed for a university admission.

For a cultivation planning approach (Hornberger, 2006, 29), there are four goals: revival, maintenance, spread, and interlingual communication-international, intranational. Based on the classroom observations, interviews, and document analyses, the EFL teachers in the study understood the goals of the English language policy in the Basic Education Core Curriculum B.E. 2551 (A.D. 2008) as 'spread' and 'interlingual communication-international, intranational.'

As defined by Nahir (2003, p.431), 'spread' is the attempt to increase the number of speakers of one language at the expense of another language. In Thailand, English allows those who learn and use it to have greater access to political and economic power (Baker, 2008; Keyuravong, 2010; Otsu, 2017). 'Spread' in the context of this study is not inferred directly to increase the number of speakers of English but instead to make students have positive attitudes and be aware of the importance of learning English rather than other foreign languages. It is like a motivation for students to learn English since it is one of the learning areas they have to take in the Ordinary National Test (O-NET). If they get good O-NET scores, they will have more chances to get into a good university. Consequently, if they have a good command of English, they will have more chances to get a well-paid job in the future. Both teachers in this study always stressed the importance in learning English in their classes. One of them even had her students practice 2-3 questions of the past O-NET at the beginning of her class. In addition, they both had students present short English conversations or useful words at the school morning assembly so that they might have a good attitude toward English and might have more confidence in using it.

'International communication' refers to the facilitation of linguistic communication between members of distinct speech communities (Hayes, 2017; Nahir, 2003). There are two types of it: 'international communication'-the communication practice that occurs across international borders; and 'intranational communication'-the communication that occurs within the nation. For the current study, both EFL teachers seemed to adopt the goal of 'intranational communication' in their practices. What both of them did in their classrooms reflected the facilitation of English communication between them and the students. Basic expressions and questions were used to facilitate the communication between the teachers and the students. For example, "Louder, please"; "What does this word mean?"; "Where is your book?". Giving an example to elicit the meaning of the vocabulary was also used by both of them.

\subsection{Implication for Teachers}

First, the study illustrates the need for teachers to include aspects of Thai culture and local community in their lessons. As the teachers have already been encouraged to create materials that are related to their local context, incorporating the students' cultural content in the teaching materials could be beneficial to the students. For 
example, for the topic of greeting, the content about Thai greeting can be added into the actual lesson that the teachers have in the textbook. It can be in a form of short dialog or reading text for students to read. Doing this, students will have a chance to learn about the topics and vocabularies relating to their own culture or local context in English so that they can interact with people from different cultural backgrounds. This can be considered a good motivation for students to learn as well since they can connect to what they learn.

Second, this study also shows the need for teachers to implement more on authentic assessment. In addition to assess student's learning from multiple choice tests and student's assignments, the teachers should consider to evaluate their students' communicative language skills utilizing speaking or listening tests. In order to truly assess the students' communicative language ability, the oral English proficiency test should be taken into consideration. For example, the ACTFL Oral Proficiency Interview (OPI) (Breiner-Sanders, Lowe Jr, Miles, \& Swender, 2000), which assesses language proficiency in terms of the speaker's ability to use the language effectively and appropriately in real-life situations, can benefit Thai EFL teachers and students.

\subsection{Implication for Policymakers}

First, the study supports the need for the office of Basic Education Commission (OBEC), Ministry of Education to provide suitable professional development and training for the teachers. It is important that teachers be given more effective training aimed at improving four main areas: knowledge of student-centered and communicative approach to teaching English, teaching techniques, material development, and communicative language assessment. Importantly, the training should be given on a regular basis over an extended period of time.

Second, this study also illustrates the need for the office of Basic Education Commission (OBEC), Ministry of Education to create supplementary material that incorporates Thai culture into the English lessons. This would allow teachers who do not have time to produce their own cultural teaching materials to use it to supplement their main teaching material at school.

Third, this study does suggest the need for the office of Basic Education Commission (OBEC), Ministry of Education to create the core materials that reflect both the main goals of the English language policy and the main aspects of the Ordinary National Education Test (O-NET). This would allow the teachers to have some level of equality in accessing to materials; this would reduce some of their pressure on the teachers' work as well.

\section{CONCLUSION}

Based on the data from classroom observations of both Kwan and Nattaporn, 84\% can be viewed as 'foreign language/second language/literacy' in acquisition planning. In addition, $15 \%$ can be viewed as both 'foreign language/second language/literacy' and 'interlingual communication' in both acquisition planning 
and status planning. And $1 \%$ can be viewed as both 'foreign language/second language/literacy' and 'spread' in both acquisition planning and status planning

Based on the data from the interviews of both EFL teachers, $85 \%$ can be viewed as 'foreign language/second language/literacy' in acquisition planning. A portion $(8.5 \%)$ of interview data can be viewed as both 'foreign language/second language/literacy' and 'spread' in both acquisition planning and status planning. In addition, $4.5 \%$ of the interview data can be viewed as both 'foreign language/second language/literacy' and 'interlingual communication' in both acquisition planning and status planning. Finally, $2 \%$ of the interview data can be viewed as 'foreign language/second language/literacy', 'spread', and 'interlingual communication' in both acquisition planning and status planning (see Figure 7).

According to the data from classroom observations and interviews, it can be concluded that both Kwan and Nattaporn understood the goals of the English language policy in the Basic Education Core Curriculum B.E. 2551 (A.D. 2008) mainly as 'foreign language/secondary language/literacy' in acquisition planning and some of their understandings touched on the concepts of 'spread' and 'interlingual communication' in status planning.

\section{REFERENCES}

Assavanonda, A. (2013, December, 16). Thailand lagging behind in English. The Nation. Retrieved from http://www.nationmultimedia.com/national/Thailandlagging-behind-in-English-30222171.html

Baker, W. (2008). A critical examination of ELT in Thailand: The role of cultural awareness. RELC Journal, 39(1), 131-146.

Breiner-Sanders, K., Lowe Jr, P., Miles, J., \& Swender, E. (2000). ACTFL proficiency guidelines-speaking revised 1999. Foreign Language Annuals, 33(1), 13-18.

Chan, C. and Lo, M. (2017). Exploring inclusive pedagogical practices in Hong Kong primary EFL classrooms. International Journal of Inclusive Education, 21(7)714-729.

Darasawang, P. (2007). English language teaching and education in Thailand: A decade of change. In N. D. Prescott (Ed.), English in Southeast Asia: Varieties, literacies and literatures (pp. 187-204). Cambridge: Cambridge Scholars Publishing.

Darasawang, P., \& Watson Todd, R. (2012). The effect of policy on English language teaching at secondary schools in Thailand. In E. Low \& H. Azirah (Eds.), English in Southeast Asia: Features, policy and language in use (pp. 207-220). Amsterdam: John Benjamins.

Fitzpatrick, D. (2011). Making sense of the English language policy in Thailand: An exploration of teachers' practices and dispositions (Unpublished doctoral dissertation). University of Exeter, United Kingdom.

Fry, G. W., \& Bi, H. (2013). The evolution of educational reform in Thailand: The Thai educational paradox. Journal of Educational Administration, 50(3), 290319.

Indonesian Journal of EFL and Linguistics, 2(2), 2017 
Gall, M. D.,Gall, J. P., \& Borg, W. R. (2007). Educational research: An introduction $\left(8^{\text {th }}\right.$ ed.). Boston: Allyn \& Bacon.

Hayes, D. (2017). Fallacies affecting policy and practice in the teaching of English as a foreign language in state primary schools in Asia. Asia Pacific Journal of Education, 37(2)179-202.

Hornberger, N. H. (2006). Frameworks and models in language policy and planning. In T. Ricento (Ed.), An introduction to language policy: Theory and method (pp. 24-41). Malden, MA: Blackwell Publishing.

Kachru, B. (1998). English as an Asian language. Links \& Letters, 5, 89-108.

Kaplan, R.B., \& Baldauf Jr., R.B. (2005). Language-in-education policy and planning. In E. Hinkel (Ed.), Handbook of research in second language teaching and learning (pp. 1013-1034). Mahwah, NJ: Lawrence Erlbaum Associates.

Keyuravong, S. (2010). Insights from Thailand. In R. Johnstone (Ed.), Learning through English: Policies, challenges and prospects: Insights from East Asia (pp. 69-95). Malaysia: British Council.

Kirkpatrick, A. (2012). English in ASEAN: Implication for regional multilingualism. Journal of Multilingual and Multicultural Development, 33 (4), 331-344.

Kolouriotis, J. (2011). Ethical considerations in conducting research with non-native speakers of English. TESL Canada Journal/Revue TESL du Canada, 28, 1-15.

Li, M. (2017). Power relations in the enactment of English language education policy for Chinese schools, Discourse, 38 (5), 627-641.

Li, Y. (2011). Translating interviews, translating lives: Ethical considerations in cross-language narrative inquiry. TESL Canada Journal/Revue TESL $d u$ Canada, 28, 16-30.

Lincoln, Y. S., \& Guba, E. G. (1985). Naturalistic inquiry. Newbury Park, CA: Sage.

Marshall, M., \& Rossman, G. (2011). Designing qualitative research. Thousand Oaks, CA: Sage.

Ministry of Education.(2008). The Basic Education Core Curriculum B.E. 2551 (A.D. 2008). Bangkok: The Express Transportation Organization of Thailand.

Nahir, M. (2003). Language planning goals: A classification. In C.B. Paulston \& G.R. Tucker (Eds.), Sociolinguistics: The essential reading (pp. 423-448). Malden, MA: Blackwell Publishing.

Nonkukhetkhong, K., Baldauf, R. B. Jr., \& Moni, K. (2006, January). Learnercenteredness in teaching English as a foreign language. Paper presented at 26th Thai TESOL International Conference. Chiang Mai, Thailand.

Noom-ura, S. (2013). English-teaching problems in Thailand and Thai teachers' professional development needs. English Language Teaching, 6 (11), 139-147. doi:10.5539/elt.v6n11p139

Nunan, D. (2003). The impact of English as a global language on educational policies and practices in the Asia-Pacific region. TESOL Quarterly, 37(4), 589-613.

Otsu, A. (2017). The gap between educational policies and actual workplace 
communicationin EFL: A Japanese case. Eurpoean Journal of Language Policy, 9(1)105-118.

Prapaisit de Segovia, L. \& Hardison, D. M. (2009). Implementing education reform: EFL teachers' perspectives. ELT Journal, 63(2), 154-162.

Ricento, T. (2006). Language policy: Theory and practice-An introduction. In T. Ricento (Ed.), An introduction to language policy: Theory and method (pp. 10-23). Malden, MA: Blackwell Publishing.

Shohamy, E. (2006). Language policy: Hidden agendas and new approaches. New York: Routledge.

Swanborn, P. (2010). Case study research: What, why, and how? Thousand Oaks, CA: Sage.

Tongpoon-Patanasorn, A. (2011). Impact of learner-centeredness on primary school teachers: A case study in Northeast Thailand. The Journal of Asia TEFL, 8 (3), $1-28$.

Ushioda, E. (2017). The Impact of Global English on Motivation to Learn Other Languages: Toward an Ideal Multilingual Self. Modern Language Journal, 101(3) 469-482.

Wongsothorn, A. (2000). Thailand. In H. Wah Kam \& Ruth Y.L. Wong (Eds.), Language policies and language education: The impact in East Asian countries (pp. 307-320). Singapore: Time Academic Press.

Yin, R. K. (2003). Case study research: Design and methods (3rd ed.). Thousand Oaks, CA: Sage. 